\title{
Recombinant Human Tissue Transglutaminase for Diagnosis and Follow-Up of Childhood Coeliac Disease
}

\author{
TONY HANSSON, INGRID DAHLBOM, SIV ROGBERG, ANDERS DANNÆUS, PETER HÖPFL, \\ HEIDI GUT, WOLFGANG KRAAZ, AND LARS KLARESKOG \\ Department of Rheumatology, Karolinska Hospital, Stockholm, Sweden [T.H., S.R., L.K.]; Pharmacia \\ Diagnostics, Uppsala, Sweden [I.D.]; Department of Pediatrics [A.D.] and Pathology [W.K.], Uppsala \\ University Hospital, Uppsala, Sweden; and Pharmacia Diagnostics, Freiburg, Germany [P.H., H.G.]
}

\begin{abstract}
Highly discriminatory markers for celiac disease are needed to identify children with early mucosal lesions and for rapid follow-up. The aim of this study was to evaluate the potential of circulating anti-tissue transglutaminase (tTG) IgA and IgG antibodies in the diagnosis and follow-up of childhood celiac disease. An ELISA using recombinant human tTG was used to measure the levels of $\operatorname{IgA}$ and IgG anti-tTG antibodies in 226 serum samples from 57 children with biopsy-verified celiac disease, 29 disease control subjects, and 24 healthy control subjects. All samples were also analyzed for anti-endomysium antibodies (EMA). The levels of IgA and IgG anti-tTG antibodies correlated with the condition of the small intestinal villous structure and the serum levels of IgA EMA. All of the 25 serum samples obtained from untreated patients contained IgA anti-tTG antibodies, and 24 of 25 also had IgA EMA. Of the serum samples from 53 control children, two had IgA anti-tTG antibodies and two had IgA EMA. Children younger than $5 \mathrm{y}$ of age with untreated celiac disease had the highest serum levels of both
\end{abstract}

\section{ABSTRACT}

$\operatorname{Ig} \mathrm{A}$ and $\operatorname{IgG}$ anti-tTG. There was already an increase in $\operatorname{IgA}$ anti-tTG antibodies after 2 wk of gluten challenge $(p<0.01)$. Although the criteria-based diagnosis of childhood celiac disease still depends on histologic evaluation of intestinal biopsies, detection of anti-tTG antibodies provides useful complementary diagnostic information. The human recombinant tTG-based ELISA can be used as a sensitive and specific test to support the diagnosis and may also be used in the follow-up of treatment in childhood celiac disease. (Pediatr Res 51: 700-705, 2002)
AGA, anti-gliadin antibodies
AU, arbitrary unit
EMA, anti-endomysium antibodies
GC, gluten challenge
IEL, intraepithelial lymphocytes
tTG, tissue transglutaminase

Abbreviations
Patients with celiac disease present a large spectrum of different nonspecific symptoms, and the classic description of the disease is probably only one end of the broad spectrum of gluten-induced disorders. By definition, a biopsy from the proximal small intestine is essential for diagnosis, and celiac disease is verified with at least one intestinal biopsy exhibiting villous atrophy (1). Diagnostic difficulties therefore arise when only minor pathologic changes in the mucosal morphology or an increased density of IEL are observed.

Elevated levels of circulating IgA and IgG AGA and IgA EMA are common in patients with celiac disease, and assess-

Received February 16, 2001; accepted November 15, 2001.

Correspondence and reprint requests: Tony Hansson, Ph.D., Department of Rheumatology, CMM L8:04, Karolinska Hospital, SE-171 76 Stockholm, Sweden; e-mail: Tony.Hansson@cmm.ki.se

Supported by the Swedish Association against Asthma and Allergy, Agnes and Mac Rudbergs Foundation, Vårdalstiftelsen and the Swedish Medical Research Council.

DOI: 10.1023/01.PDR.0000015105.38277.9B ment of these antibodies is generally used as an aid in diagnosis (2). However, some celiac patients do not have increased levels of AGA and EMA, and when elevated, the different antibody levels decrease slowly, only being reduced after 3-12 mo of gluten restriction (3).

tTG was identified in 1997 as the main target antigen for the endomysial antibodies (4). tTG has been demonstrated in many different human tissues such as skin, liver, and the jejunal mucosa (5). tTG is involved in cell adhesion, extracellular matrix assembly, and wound healing mechanisms (6-8), and wheat gliadins can act as a substrate for transglutaminase reactions $(9,10)$. It has also been shown that tTG selectively deamidates gliadin peptides, which leads to strongly enhanced reactivity of gliadin-specific gut-derived T cells $(11,12)$.

Measurements of serum IgA antibodies against tTG can be used as sensitive and specific markers for untreated celiac disease. Assays for detection of IgA anti-tTG antibodies have a sensitivity of 92 to $100 \%$ and a specificity of 90 to $98 \%$ 
(13-20). Recent reports have indicated that tTG assays can be further improved by using human tTG instead of guinea pig tTG $(18,20-22)$.

However, there is still some doubt as to whether recombinant human tTG can be used with the same diagnostic sensitivity and precision as the EMA assay and whether recombinant human tTG is a more sensitive and specific marker than EMA for celiac disease in the youngest children. We have therefore studied a large group of children with biopsy-verified celiac disease and control subjects with other gastrointestinal diseases to investigate the clinical potential of recombinant human tTG in the diagnosis and follow-up of childhood celiac disease.

\section{PATIENTS AND METHODS}

Patients. Included in this study were 86 children with gastrointestinal symptoms and suspected malabsorption. Disease was diagnosed in all children at the Department of Paediatrics, Uppsala University Hospital, and during the investigation celiac disease was evident in 57 children ( 31 girls, 26 boys; median age, $4 \mathrm{y}$; range, 1-16 y). The diagnosis was confirmed according to the original European Society for Pediatric Gastroenterology, Hepatology and Nutrition (ESPGHAN) criteria (23) or according to the revised criteria for diagnosis of childhood celiac disease (1).

Small intestinal biopsies were performed in all children, and included in this study were 25 biopsies from untreated patients, 21 biopsies after 1-3 y on a gluten-free diet, and 38 biopsies after 12 wk of GC. Forty of the celiac children had a blood sample taken after 2 wk of GC. All the challenged children had a normal gluten-containing diet with the recommendation that the daily gluten load should be at least equivalent to $2-3$ pieces of bread.

After extensive diagnostic examination, 29 children (16 girls, 13 boys; median age, $5 \mathrm{y}$; range, $1-18$ y) were shown to have disorders other than celiac disease. In this disease control group two had inflammatory bowel disease, nine had cow's milk intolerance, three had other food intolerances, and 15 had transient gastrointestinal disorders. All of the disease control subjects underwent a small intestinal biopsy, and 24 biopsies were included in the study.

Twenty-four children (11 girls, 13 boys; median age, 5 y; range, 1-16 y) without any gastrointestinal symptoms and without relatives with celiac disease served as healthy control subjects. All studies of patients and control subjects were performed in accordance with the ethical rules of the hospital.

Anti-tTG antibodies. IgA and IgG antibodies to tTG in serum were determined with an ELISA (research prototype, Pharmacia Diagnostics, Freiburg, Germany). Microplate strips coated with recombinant human $\mathrm{tTG}$ produced in the Baculo/Sf9 system at optimal concentration were used. The recombinant human tTG had a purity of $99 \%$ and inhibited IgA endomysial binding from celiac disease patient sera to monkey esophagus more efficiently than guinea pig tTG and gave an equivalent inhibition to native tTG from human erythrocytes (24).

Patient sera were diluted in PBS with $1 \%$ BSA and $0.1 \%$ sodium azide (PBS-BSA) to suitable concentrations. Patient serum $(100 \mu \mathrm{L})$ was added, and the strips were incubated for $30 \mathrm{~min}$ at room temperature and washed three times with PBS.
Horseradish peroxidase-conjugated anti-human $\operatorname{IgA}$ or $\operatorname{IgG}$ antibodies was added, and after $30 \mathrm{~min}$ at room temperature the plates were washed three times.

A substrate solution containing 3,3',5,5' tetramethylbenzidine was added, and the reaction was stopped after $10 \mathrm{~min}$ at room temperature with $0.5 \mathrm{M} \mathrm{H}_{2} \mathrm{SO}_{4}$. The absorbance was measured at $450 \mathrm{~nm}$.

Anti-tTG IgA antibody calibrators, a negative control, and diluent blanks were included in each assay. The antibody concentrations were expressed as AU per milliliter, and serum samples with absorbances above the highest calibrator were diluted further and reassayed. The intra- and interassay variations were less than $10 \%$.

Cutoff for the tTG assays was determined by receiver operating characteristic curves (25), and the cutoff levels were 4.7 $\mathrm{AU} / \mathrm{mL}$ for the IgA tTG assay and $1.2 \mathrm{AU} / \mathrm{mL}$ for the IgG tTG assay.

EMA analysis. IgA EMA were analyzed by indirect immunofluorescence microscopy using fixed cryostat sections of monkey esophagus (Scimedx, Densville, NJ, U.S.A.) as an antigen substrate (26). Patient sera were diluted $1 / 10$, and positive sera were also investigated at dilutions of $1 / 50,1 / 100$, $1 / 500$, and $1 / 1000$. The antibody titer was defined as the highest serum dilution yielding fluorescence.

AGA-producing cells. Peripheral blood mononuclear cells were obtained from heparinized venous blood by separation on Ficoll-Paque (Amersham Pharmacia Biotech, Uppsala, Sweden). Cell phenotype was determined by fluorescence-activated cell sorting analysis, and 6 to $22 \%$ of the mononuclear cells were $\mathrm{CD} 45^{+} \mathrm{CD} 19^{+}$(FACSscan flow cytometer and $\mathrm{MAb}$ from Becton Dickinson, San Jose, CA, U.S.A.).

The enzyme-linked immunospot (ELISPOT) assay was performed as described elsewhere (27). Antigen specificity was demonstrated by the absence of spot-forming cells on plates coated with ovalbumin and tetanus-toxoid. Furthermore, the addition of excess gliadin $(1 \mathrm{mg} / \mathrm{mL})$ to the mononuclear cells before addition to the gliadin-coated wells inhibited spot formation 70 to $85 \%$, whereas $5 \mathrm{mg} / \mathrm{mL}$ ovalbumin had no effect.

$\boldsymbol{A G A}$. The ELISA method for detection of IgA and IgG antibodies to gliadin in serum was performed as described elsewhere (27). Positive patient sera with high concentrations of AGA were used as standards, and the antibody concentration was expressed as AU per milliliter.

Intestinal biopsy. Included in this study were 108 reexamined small intestinal biopsies, all of which were studied histologically by the same pathologist, and which were normality defined with a villous to crypt ratio of 2:1 or more (28) and an IEL count within normal limits ( $\leq 1 \mathrm{IEL} / 5$ epithelial cells) $(29,30)$.

The histopathologic changes were classified as normal mucosa, increased numbers of IEL without signs of atrophy [the IEL counts were classified according to Michaëlsson et al. (31)], partial or subtotal villous atrophy (a villous to crypt ratio distinctly less than 2:1), and total villous atrophy (flat mucosa).

Statistics. The numbers of AU per milliliter are reported as median (with 10th and 90th centiles, in brackets). The KruskalWallis test and the Mann-Whitney $U$ test (two-tailed) were used for calculation of differences in AU between different 
patient groups, and the Wilcoxon signed-rank test was used to compare the values before and after GC.

\section{RESULTS}

IgA and IgG anti-tTG antibodies. The serum levels of IgA and IgG anti-tTG antibodies in children with celiac disease and control subjects are presented in Figure 1. The children younger than $5 \mathrm{y}$ of age had consistently somewhat higher serum levels of both IgA and IgG anti-tTG antibodies than the older children.

The untreated celiac disease children had the highest levels of IgA anti-tTG [median, 958.4 (7.5-5480.6) AU/mL] and IgG anti-tTG [median, $44.8(1.3-156.0) \mathrm{AU} / \mathrm{mL}$ ]. None of the 24 healthy controls had more than $5.1 \mathrm{IgA}$ anti-tTG $\mathrm{AU} / \mathrm{mL}$ [median, $1.3(0.3-3.9) \mathrm{AU} / \mathrm{mL}$ ] or more than $1.6 \mathrm{IgG}$ anti-tTG $\mathrm{AU} / \mathrm{mL}$ [median, $0.5(0.09-1.2) \mathrm{AU} / \mathrm{mL}$ ].

Of the 46 serum samples taken from the 29 disease control subjects, one child had increased serum levels of IgA anti-tTG
(17.9 AU/mL). She was diagnosed as having cow's milk intolerance.

Small intestinal biopsy. Included in this study were 108 assessable small intestinal biopsies. Eighty-four biopsies were taken from children diagnosed with celiac disease and 24 from the disease control group. All of the children with untreated celiac disease had a total or partial or subtotal villous atrophy. None of the disease controls had villous atrophy, but one child had diarrhea and increased levels of IEL without any clinical symptoms of celiac disease.

In the normal mucosa the IEL were mainly present at the basal membrane, whereas in the mucosa with increased numbers of IEL the lymphocytes were present more apically and had a tendency to cluster.

Figure 2 depicts the levels of IgA anti-tTG antibodies compared with the small intestinal mucosal morphology. The serum levels of IgA anti-tTG were increased $(p<0.0001)$ for
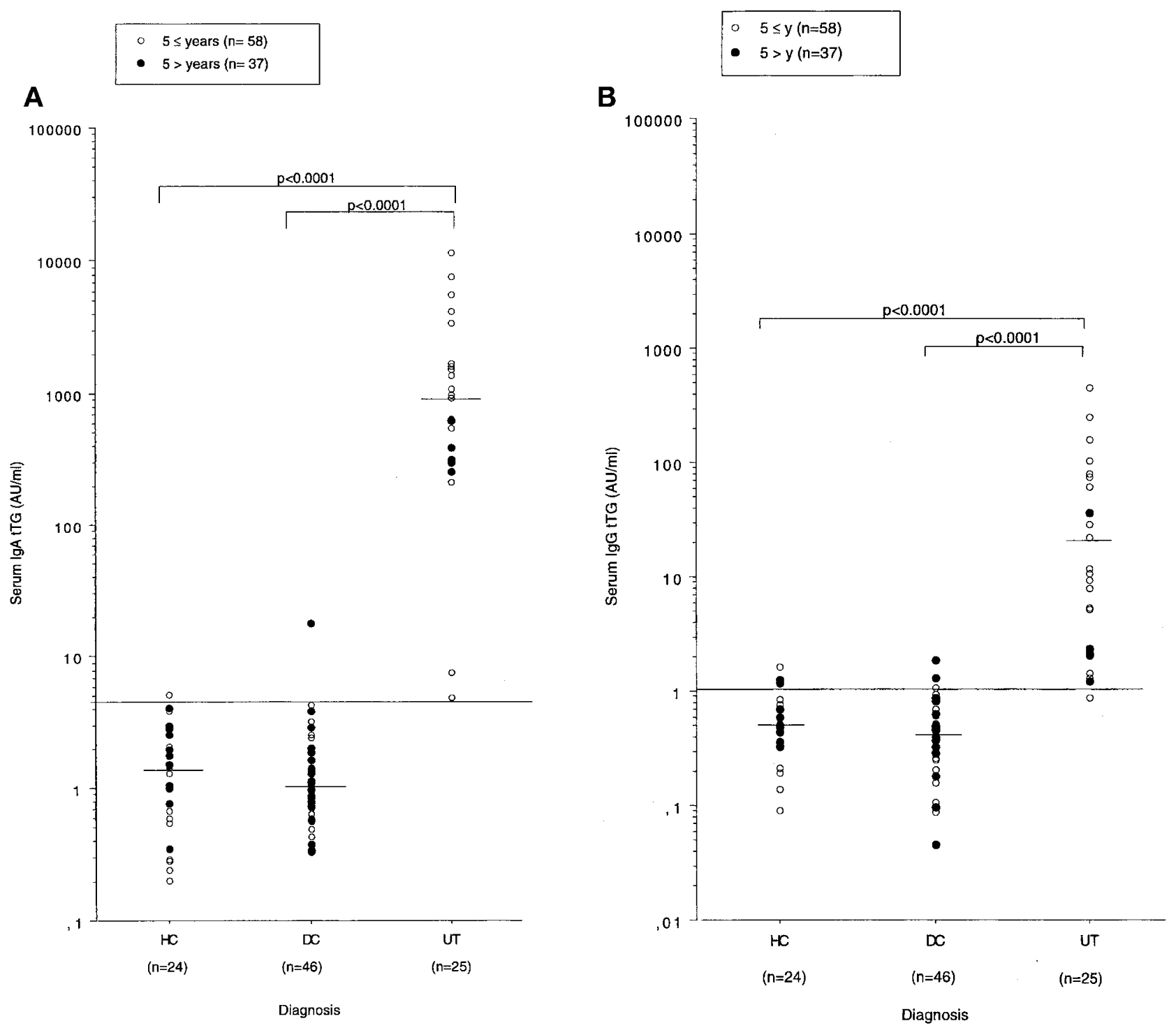

Figure 1. Serum levels of IgA antibodies $(A)$ and $\operatorname{IgG}$ antibodies $(B)$ against recombinant human tTG expressed as AU per milliliter in healthy control subjects $(H C)$, disease control subjects $(D C)$, and patients with untreated celiac disease (UT). Lines represent median values. Cutoff for the IgA anti-tTG, $4.7 \mathrm{AU} / \mathrm{mL}$, and for the IgG anti-tTG,1.2 AU/mL. 


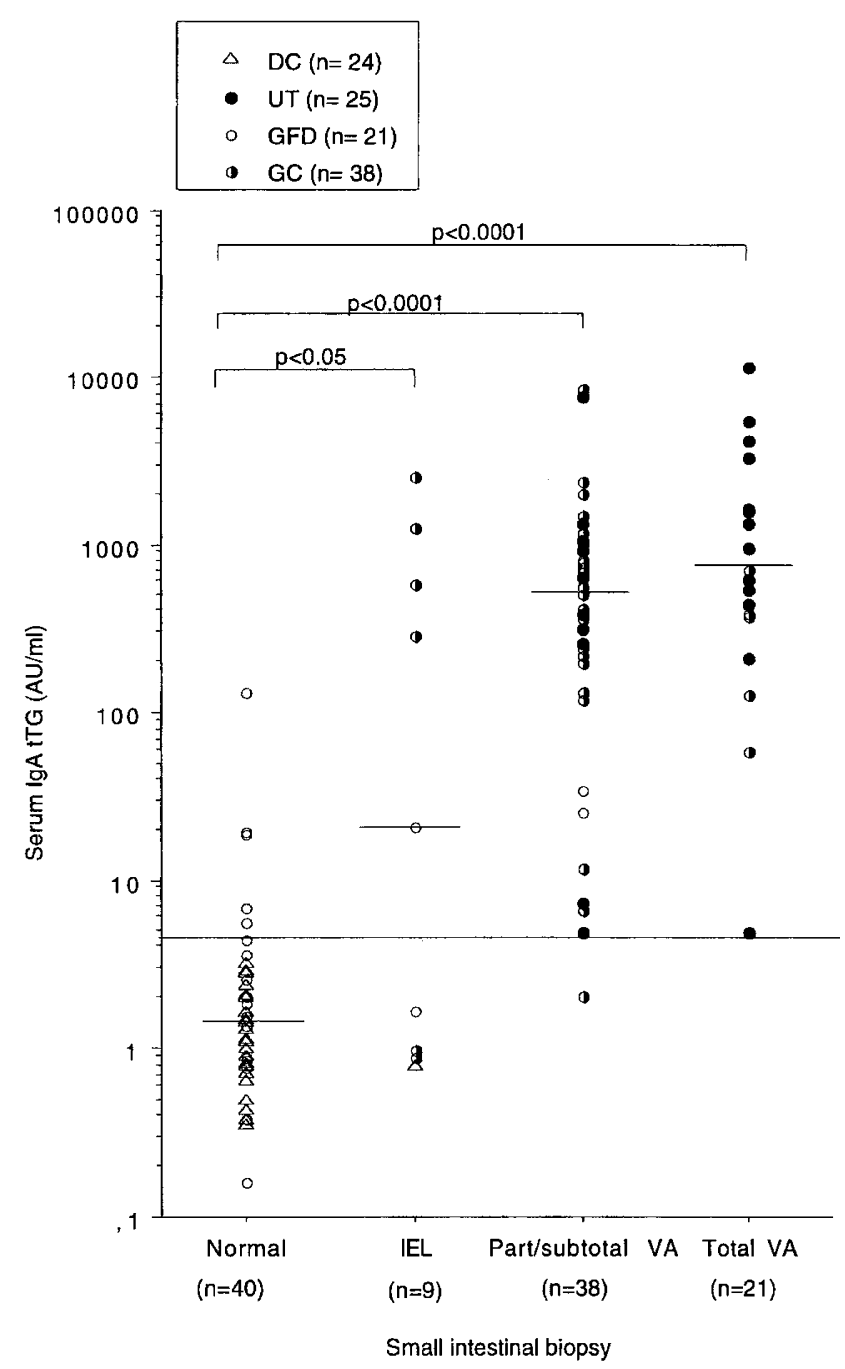

Figure 2. Serum levels of IgA antibodies against recombinant human tTG expressed as AU per milliliter in disease control subjects $(D C)$, patients with untreated celiac disease (UT), patients after gluten-free diet $(G F D)$, and patients after GC compared with the histopathology of the small intestinal mucosa (VA, villous atrophy; Part/subtotal VA, a villous to crypt ratio distinctly less than $2: 1 ; p$ values $v s$ normal). Lines represent median values. Cutoff, 4.7 AU/mL.

both the patients with total villous atrophy [median, 710.6 (9.4-4839.2) AU/mL] and for the patients with partial or subtotal villous atrophy [median, $531.9(8.8-1869.8) \mathrm{AU} / \mathrm{mL}$ ] compared with the normal biopsies [median, $1.4(0.4-6.2)$ $\mathrm{AU} / \mathrm{mL}]$.

Of the 21 children on a gluten-free diet, two had a partial or subtotal villous atrophy, two had increased numbers of IEL, and all four had elevated serum levels of IgA EMA.

A mucosa with a normal villous to crypt ratio but increased numbers of IEL was evident in six celiac disease patients after 12 wk of GC, and after a prolonged GC all six were diagnosed as having celiac disease in accordance with their clinical symptoms. Four of these children had increased serum levels of both IgA anti-tTG and IgA EMA.

IgA anti-tTG antibodies during gluten challenge. After more than $1 \mathrm{y}$ of a gluten-free diet, four of 18 children with celiac disease had increased serum levels of IgA anti-tTG antibodies [median, $1.9(0.9-22.3) \mathrm{AU} / \mathrm{mL}$ ] and four of $18 \mathrm{had}$ IgA EMA. None of the children had increased numbers of IgA AGA spot-forming cells after a gluten-free diet.

The serum levels of IgA anti-tTG antibodies increased $(p<$ $0.01)$ after 2 wk of GC [median, $2.9(0.8-200.7) \mathrm{AU} / \mathrm{mL}$ ] compared with the serum levels before challenge and continued to increase $(p<0.0001)$ after $12 \mathrm{wk}$ of GC [median, 575.5 (2.5-1487.9) AU/mL; Fig. 3].

Sensitivity and specificity of the different markers in detection of celiac disease. The sensitivity and specificity of the different markers of celiac disease are summarized in Table 1. The IgA anti-tTG ELISA exhibited a sensitivity of $100 \%$ as

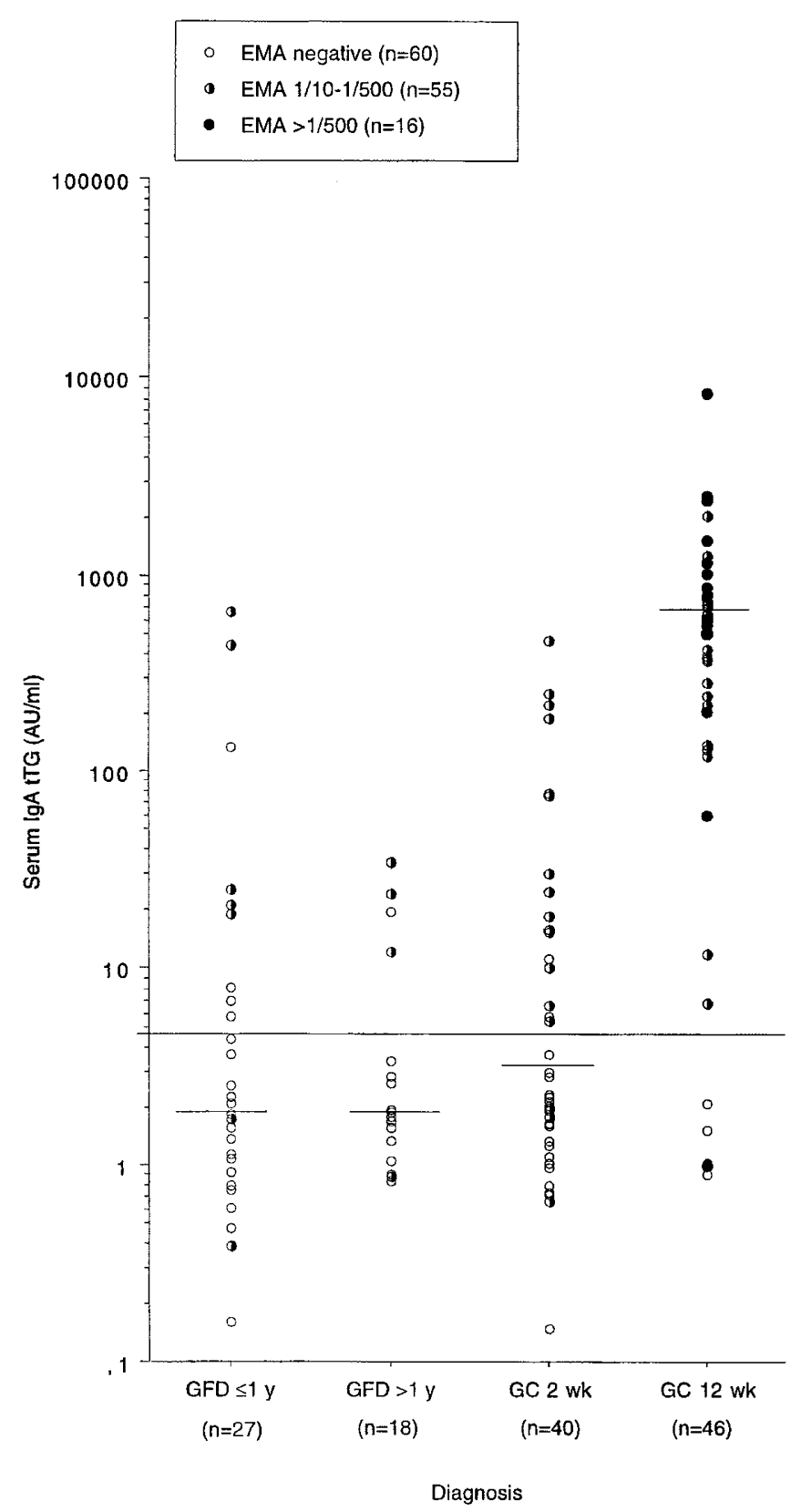

Figure 3. Serum levels of IgA antibodies against recombinant human tTG expressed as AU per milliliter in celiac disease patients after gluten-free diet $(G F D)$ and after $2 \mathrm{wk}$ and $12 \mathrm{wk}$ of GC. Lines represent median values. Cutoff, 4.7 $\mathrm{AU} / \mathrm{mL}$ 
Table 1. Comparison of sensitivity and specificity of human recombinant IgA and IgG tTG assay, the serum IgA EMA test, the serum IgA and IgG AGA assay, and the AGA spot-forming cell AGA SFC test*

\begin{tabular}{|c|c|c|c|c|c|c|c|c|}
\hline Antibody & $\begin{array}{c}\text { Sensitivity } \\
(\%)\end{array}$ & $\begin{array}{c}\text { Specificity } \\
(\%)\end{array}$ & Untreated celiac disease & Nonceliac disease & $\mathrm{GFD} \leq 1 \mathrm{y}$ & $\mathrm{GFD}>1 \mathrm{y}$ & GC $2 \mathrm{wk}$ & GC 12 wk \\
\hline IgA recombinant tTG & 100 & 96 & $25 / 25$ & $2 / 53$ & $9 / 27$ & $4 / 18$ & $18 / 40$ & $41 / 46$ \\
\hline IgG recombinant tTG & 96 & 91 & $24 / 25$ & $5 / 53$ & $7 / 27$ & $3 / 18$ & $7 / 40$ & $34 / 46$ \\
\hline IgA EMA & 96 & 96 & $24 / 25$ & $2 / 53$ & $7 / 27$ & $4 / 18$ & $18 / 40$ & $42 / 46$ \\
\hline IgA AGA & 96 & 89 & $24 / 25$ & $6 / 53$ & $2 / 27$ & $0 / 18$ & $10 / 40$ & $40 / 46$ \\
\hline IgG AGA & 84 & 92 & $21 / 25$ & $4 / 53$ & $2 / 27$ & $0 / 18$ & $3 / 40$ & $32 / 46$ \\
\hline IgA AGA SFC & 92 & 89 & $23 / 25$ & $6 / 53$ & $0 / 27$ & $0 / 18$ & $31 / 40$ & $41 / 46$ \\
\hline
\end{tabular}

* Data in the last six columns represent numbers of patients with positive test results/total numbers of patients tested. GFD, gluten-free diet.

compared with $96 \%$ for the IgA EMA test. The specificity of the IgA anti-tTG ELISA and the IgA EMA tests was $96 \%$.

After $2 \mathrm{wk}$ of GC, 18 of 40 children had a increased serum levels of IgA anti-tTG antibodies and IgA EMA, and 31 of 40 children had increased numbers of circulating IgA AGA spotforming cells.

After 12 wk of GC, 41 of 46 children had a increased serum levels of IgA anti-tTG antibodies and increased numbers of circulating IgA AGA spot-forming cells, and 42 of 46 children had increased serum levels of IgA EMA.

\section{DISCUSSION}

This study was concerned with the use of a recombinant human tTG ELISA as a diagnostic method for childhood celiac disease, and whether this assay can be used in young children as an alternative to the laborious EMA assay and less sensitive AGA assay.

Human tTG assays have previously been shown to have a higher sensitivity and specificity than assays based on guinea pig tTG both in adults and children (18, 20-22). This may be owing to the small differences in the amino acid sequences of guinea pig tTG and human tTG, or antibody reactivity against contaminating proteins from partially purified guinea pig liver tTG. As most of the performed studies so far have used ELISAs with guinea pig $\mathrm{tTG}$, there has accordingly been a need for large studies focused on reactivity toward human $\mathrm{tTG}$, and in this study we have used recombinant human $\mathrm{tTG}$ for this purpose.

Our study showed a very high concordance in results between the EMA test and the present recombinant human ELISA, and the IgA anti-tTG ELISA displayed a sensitivity of $100 \%$ and the same specificity $(96 \%)$ as the IgA EMA assay in the investigated patients, which included a large group of children with other gastrointestinal disorders and food intolerances. Thus, the vast majority of both untreated and GC children with celiac disease were positive for both IgA antitTG and IgA EMA. A few patients were, however, positive for only one of the tests, i.e. one celiac child with untreated disease was negative for EMA but anti-tTG antibody was positive whereas one GC child had a positive EMA test and was negative for IgA anti-tTG. Both these children had a partial or subtotal villous atrophy. These discrepancies may be explained by differences in the specificity of the different antibodies and might indicate that tTG is not the only antigen for celiac disease-associated autoantibodies.

The IgG anti-tTG antibodies also correlated with the diagnosis and with the condition of the small intestinal villous structure. The presently used IgG anti-tTG ELISA exhibited a high sensitivity (91\%) and specificity (96\%), whereas other recent studies have reported a sensitivity between $21 \%$ and $98 \%(19,21,32)$. Detection of IgG anti-tTG antibodies may thus be useful for the diagnosis of celiac disease in patients with selective IgA deficiency (33); this issue needs to be further investigated.

After more than 1 y of a gluten-free diet, elevated levels of IgA anti-tTG antibodies remained in four of 18 of the children with celiac disease, and after $12 \mathrm{wk}$ of GC 41 of 46 of the celiac children had increased levels of IgA anti-tTG antibodies. These results indicate that measurements of anti-tTG antibodies can be used in the follow-up of diet compliance and GC. Korponay-Szabó et al. (34) have proposed that GC could be advisable in some patients with initial villous atrophy and negative EMA results.

We have earlier reported that the appearance of circulating IgA AGA-producing cells is a reproducible finding in children with celiac disease and that there is a rapid increase in the numbers of IgA AGA spot-forming cells during GC (27). None of the children included in the present study had increased numbers of circulating IgA AGA spot-forming cells after a gluten-free diet. However, an increase in the numbers of circulating IgA AGA spot-forming cells was apparent in 31 of 40 children after 2 wk of GC. These data emphasize that a possible use of the ELISPOT assay may be found in monitoring changes in actual production of AGA for example in the evaluation of different immunotherapeutic trials.

In summary, we have demonstrated that detection of antitTG antibodies can be used to distinguish between children with celiac disease and children with other gastrointestinal disorders. The human recombinant tTG-based ELISA is a sensitive, specific, and reproducible test to support the diagnosis and follow-up of childhood celiac disease and can be used as an alternative to the EMA test. However, further study remains to be undertaken to determine whether the use of recombinant human tTG can accurately detect $100 \%$ of the celiac patients $(20,35,36)$ and thereby to which extent it might in the future replace intestinal biopsy for diagnosis of celiac disease in childhood.

Acknowledgments. The authors thank Sonja Gertz for invaluable help in recruiting the children involved in this study and Dr. R.A. Harris for linguistic advice. 


\section{REFERENCES}

1. Walker-Smith JA, Guandalini S, Schmitz J, Shmerling DH, Visakorpi JK 1990 Revised criteria for diagnosis of coeliac disease. Arch Dis Child 65:909-911

2. Fasano A, Catassi C 2001 Current approaches to diagnosis and treatment of celiac disease: an evolving spectrum. Gastroenterology 120:636-651

3. Scott H, Kett K, Halstensen T, Hvatum M, Rognum TO, Brandtzaeg P 1992 The humoral immune system in coeliac disease. In: Marsh MN (ed) Coeliac Disease. Blackwell, Oxford, pp 239-282

4. Dieterich W, Ehnis T, Bauer M, Donner P, Volta U, Riecken EO, Schuppan D 1997 Identification of tissue transglutaminase as the autoantigen of celiac disease. Nat Med 3:797-801

5. Bruce SE, Bjarnason I, Peters TJ 1985 Human jejunal transglutaminase: demonstration of activity, enzyme kinetics and substrate specificity with special relation to gliadin and coeliac disease. Clin Sci 68:573-579

6. Upchurch HF, Conway E, Patterson MKJ, Maxwell MD 1991 Localization of cellular transglutaminase on the extracellular matrix after wounding: characteristics of the matrix bound enzyme. J Cell Physiol 1249:375-382

7. Aeschlimann D, Paulsson M 1994 Transglutaminases: protein cross-linking enzymes in tissue and body fluids. Thromb Haemost 71:402-415

8. D'Argenio G, Cosenza V, Sorrentini I, De Ritis F, Gatto A, Delle Cave M, D'Armiento FP, Mazzacca G 1994 Butyrate, mesalamine and factor XIII in experimental colitis in the rat: effects on transglutaminase activity. Gastroenterology 106:399-404

9. Szabolcs M, Sipka S, Csorba S 1987 In vitro cross-linking of gluten into highmolecular-weight polymers with transglutaminase. Acta Paediatr Hung 28:215-227

10. Larre C, Chiarello M, Blanloeil Y, Chenu M, Gueguen J 1993 Gliadin modifications catalyzed by guinea pig liver transglutaminase. J Food Biochem 17:267-282

11. Molberg Ø, Mcadam SN, Körner R, Quarsten H, Kristiansen C, Madsen L, Fugger L Scott H, Norén O, Roepstorff P, Lundin KEA, Sjöström H, Sollid LM 1998 Tissue transglutaminase selectively modifies gliadin peptides that are recognized by glutenderived $\mathrm{T}$ cells in celiac disease. Nat Med 4:713-717

12. van de Wal Y, Kooy Y, van Veelen P, Pena S, Mearin L, Papadopoulos G, Koning F 1998 Selective deamidation by tissue transglutaminase strongly enhances gliadinspecific T cell reactivity. J Immunol 161:1585-1588

13. Dieterich W, Laag E, Schöpper H, Volta U, Ferguson A, Gillet H, Riecken EO, Schuppan D 1998 Autoantibodies to tissue transglutaminase as predictors of celiac disease. Gastroenterology 115:1317-1321

14. Sulkanen S, Halttunen T, Laurila K, Kolho K-H, Korponay-Szabó I, Samesto A Savilahti E, Collin P, Mäki M 1998 Tissue transglutaminase autoantibody enzymelinked immunosorbent assay in detecting celiac disease. Gastroenterology 115:13221328

15. Malberg K, Malfertheiner P, Bannert N, Günther T 1999 IgA-tissue transglutaminase (tTG)-antibodies are highly sensitive serum markers for celiac disease. Am J Gastroenterol 94:3079-3080

16. Vitoria JC, Arrieta A, Arranz C, Ayesta A, Sojo A, Maruri N, García-Masdevall MD 1999 Antibodies to gliadin, endomysium and tissue transglutaminase for the diagnosis of celiac disease. J Pediatr Gastroenterol Nutr 29:571-574

17. Biagi F, Ellis JH, Yiannakou JY, Brusco G, Swift GL, Smith PM, Corazza GR, Ciclitira PJ 1999 Tissue transglutaminase antibodies in celiac disease. Am J Gastroenterol 94:2187-2192

18. Sárdy M, Odenthal U, Kárpáti S, Paulsson M, Smyth N 1999 Recombinant human tissue transglutaminase ELISA for the diagnosis of gluten-sensitive enteropathy. Clin Chem 45:2142-2149
19. Troncone R, Maurano F, Rossi M, Micillo M, Greco L, Auricchio R, Salerno G, Salvatore F, Sacchetti L 1999 IgA antibodies to tissue transglutaminase: an effective diagnostic test for celiac disease. J Pediatr 134:166-171

20. Hansson T, Dahlbom I, Hall J, Holtz A, Elfman L, Dannæus A, Klareskog L 2000 Antibody reactivity against human and guinea pig tissue transglutaminase in children with celiac disease. J Pediatr Gastroenterol Nutr 30:379-384

21. Bazzigaluppi E, Lampasona V, Barera G, Venerando A, Bianchi C, Chiumello G, Bonifacio E, Bosi E 1999 Comparison of tissue transglutaminase-specific antibody assays with established antibody measurements for coeliac disease. J Autoimmun 12:51-56

22. Sblattero D, Berti I, Trevisiol C, Marzari R, Tommasini A, Bradbury A, Fasano A, Ventura A, Not T 2000 Human recombinant tissue transglutaminase ELISA: an innovative diagnostic assay for celiac disease. Am J Gastroenterol 95:1253-1257

23. Meeuwisse GW 1970 Diagnostic criteria in coeliac disease. Acta Paediatr Scand 59:461-463

24. Andersson A-S, Holtz A, Backhans B, Axiö-Fredriksson U-B, Mauch L, Scheckermann C, Dahlbom I 2000 Inhibition of endomysial staining with human tissue transglutaminase. J Pediatr Gastroenterol Nutr 31(suppl 3):S16

25. Centor RM 1991 Signal detectability: the use of ROC curves and their analyses. Med Decis Making 11:102-106

26. Grodzinsky E, Jansson G, Skogh T, Stenhammar L, Fälth-Magnusson K 1995 Anti-endomysium and anti-gliadin antibodies as serological markers for coeliac disease in childhood: a clinical study to develop a practical routine. Acta Paediatr 84:294-298

27. Hansson T, Dannæus A, Kraaz W, Sjöberg O, Klareskog L 1997 Production of antibodies to gliadin by peripheral blood lymphocytes in children with celiac disease: the use of an enzyme-linked immunospot technique for the screening and follow-up. Pediatr Res 41:554-559

28. Phillips AD 1989 The small intestinal mucosa. In: Whitehead R (ed) Gastrointestinal and Esophageal Pathology. Churchill-Livingstone, Edinburgh, pp 29-39

29. Spencer JO, MacDonald TT, Diss TC, Walker-Smith JA, Ciclitira PJ, Isaacson PG 1989 Changes in intraepithelial lymphocyte subpopulations in coeliac disease and enteropathy associated T cell lymphoma (malignant histiocytosis of the intestine). Gut 30:339-346

30. Arranz E, Ferguson A 1993 Intestinal antibody pattern of celiac disease: occurrence in patients with normal jejunal biopsy histology. Gastroenterology 104:1263-1272

31. Michaëlsson G, Kraaz W, Gerdén B, Hagforsen E, Hjelmqvist G, Lööf L, Sjöberg O, Scheynius A 1995 Increased lymphocyte infiltration in duodenal mucosa from patients with psoriasis and serum IgA antibodies to gliadin. Br J Dermatol 133:896904

32. Seissler J, Boms S, Wohlrab U, Morgenthaler NG, Mothes T, Boehm BO, Scherbaum WA 1999 Antibodies to human recombinant tissue transglutaminase measured by radioligand assay: evidence for high diagnostic sensitivity for celiac disease. Horm Metab Res 31:375-379

33. Cataldo F, Lio D, Marino V, Picareli A, Ventura A, Corazza GR $2000 \operatorname{IgG}_{1}$ antiendomysium and IgG antitissue transglutaminase (anti-tTG) antibodies in coeliac patients with selective IgA deficiency. Gut 47:366-369

34. Korponay-Szabó IR, Kovács JB, Lörincz M, Gorácz G, Szabados K, Balogh M 1997 Prospective significance of antiendomysium antibody positivity in subsequently verified celiac disease. J Pediatr Gastroenterol Nutr 25:56-63

35. Brusco G, Izzi L, Corazza GR 1998 Tissue transglutaminase antibodies for coeliac disease screening. Ital J Gastroenterol Hepatol 30:496-497

36. Miller A, Paspaliaris W, Elliott PR, d'Apice A 1999 Anti-transglutaminase antibodies and coeliac disease. Aust N Z J Med 29:239-242 